\title{
FACTORS THAT PREVENT PRIMARY SCHOOL TEACHERS FROM UTILIZING COMPUTERS AND OTHER NEW TECHNOLOGICAL MEANS IN THEIR WORKPLACE: THE CASE OF PRIMARY SCHOOL TEACHERS IN THE PREFECTURE OF MAGNESIA, GREECE
}

\author{
Georgios Moutsinas ${ }^{1 *}$, Sofia Lamprianidou ${ }^{2}$, Emmanouela Mamalaki ${ }^{3}$, Aikaterini \\ Markou $^{4}$, Glykeria Moschou ${ }^{5}$, Aikaterini Papanagnou ${ }^{6}$, Efthymia Papanagnou ${ }^{7}$ \\ ${ }^{1}$ Mr., European University Cyprus, GREECE, giorgio7_cool@hotmail.com \\ ${ }^{2}$ Ms., European University Cyprus, MALTA, sofilab_1989@hotmail.com \\ ${ }^{3}$ Ms., European University Cyprus, GREECE, www.emma_nouela@hotmail.com \\ ${ }^{4}$ Ms., European University Cyprus, GREECE, www.nirvanaworld88@hotmail.com \\ ${ }^{5}$ Ms., European University Cyprus, GREECE, glykoula2009@hotmail.com \\ ${ }^{6}$ Ms., European University Cyprus, GREECE, katerina_papanagnou@hotmail.com \\ ${ }^{7}$ Ms., European University Cyprus, GREECE, eftpapan@yahoo.gr \\ ${ }^{*}$ Corresponding author
}

\begin{abstract}
In order to understand and to promote the educational integration and utilization of Information and Communication Technologies (ICT), teachers need to be investigated in-depth, as substantial determinants of the educational process, and research interest ought to be concentrated on the factors that are inhibitory to their decisions concerning the pedagogical employment of ICT. Therefore, the present paper examines three interrelated factors that prevent primary school teachers from making use of computers and of other new technological means in their workplace. Through qualitative methodology and individual structured interviews, seven (7) teachers from public primary schools of equal number, in the prefecture of Magnesia, Greece, report a) the main problems encountered in the educational use of computers, b) their beliefs about the pedagogical value of the utilization of computers in the teaching process, and c) the "official policy" of their school of service regarding the usage of computers in instructional practice. According to the findings of this study, among others, a) the quantitatively and qualitatively inadequate or insufficient school infrastructure and technical support are ascertained, whilst highlighting b) the positive learning outcomes of the said use of computers, along with schoolteacher beliefs in favor of their confined employment. Finally, c) a range of existing school policy is observed, including the formal or informal encouragement of the voluntary use of computers, or the absence of corresponding guidelines. Overall, despite their limitations, the abovementioned results can be applied to pre-service and in-service teacher training, and in the formulation of the associated educational policy, taking into account the available national financial resources.
\end{abstract}

Keywords: computers, ICT, teaching, primary school teachers, preventive factors. 


\section{INTRODUCTION}

In contemporary school, Information and Communication Technologies (ICT) are considered a key instrument of the educational process, as they can contribute to the improvement and to the reorientation of teaching and learning. For this reason, the integration of ICT in the teaching of various disciplines of the primary school curriculum constitutes an issue of high research interest. Principally, ICT can contribute to both the betterment and the change of teaching practices, as well as to the creation of new methods of teaching and learning. In this way, they provide additional meaning to the individual teaching subjects and formulate further opportunities and benefits of social interaction and of collaborative learning among students, but also of their dynamic contact with knowledge (Livingstone, 2012; Smeets, 2005).

However, despite the perceptible presence and the rapid evolution of technology in education, the difficulties and the demands, that the usage of ICT in teaching comprises, constitute a subject of intense debate (Vitanova, Atanasova-Pachemska, lliev, \& Pachemska, 2015).

Over the past few decades, all economically developed countries are attempting to incorporate the use of new technological means into teaching. Nevertheless, the integration of ICT in educational practice has not yet been achieved effectively; international and Greek research data indicate that computers are sub-used in today's school both quantitatively and qualitatively (Muir-Herzig, 2004; Vosniadou \& Kollias, 2001).

Furthermore, teachers' role is presumed of crucial importance for the educational integration of ICT. Individual teacher characteristics, such as self-efficacy regarding the use of computers, beliefs anent the integration of new technological means into teaching practice, and teachers' gender, but also environmental features, such as school unit and colleagues, seem to be linked to the usage of new technologies in teaching (Afshari, Bakar, Luan, Samah, \& Fooi, 2009). Therefore, in order to understand the issue of the pedagogical integration and utilization of ICT, while advancing future instructional practices, teachers need to be investigated themselves, as substantial determinants of the educational process, and research interest ought to be focused on the factors that are inhibitory to their decisions concerning the pedagogical employment of ICT.

\section{THEORETICAL FRAMEWORK}

\subsection{Preventive Factors For The Educational Use Of ICT: Review Of The Literature}

The use of ICT in education represents one of the fundamental issues of modern school. Notwithstanding, it is observed that their indicated utilization varies; in reality, several parameters exist, influencing teachers and schools in terms of the pedagogical inclusion of ICT, but also towards the form and the extent of their integration into teaching (Buabeng-Andoh, 2012). In this context, previous empirical studies have highlighted specific factors that affect in an inhibitory way the particular usage of new technological means by educators.

In the survey of Badia, Meneses, and Sigalés, in 2013, on 278 primary school teachers, the negative schoolteacher perceptions as to the utility of new technological means in the teaching process $(29.89 \%)$, the lack of the provided advisory support $(10.83 \%)$, the inadequacy and the low accessibility of the material and technical infrastructure at in-school $(6.51 \%)$ and at extracurricular level $(6.21 \%)$, along with the inefficiency of the required teacher expertise $(7.75 \%)$, were identified as impediments to the educational use of ICT.

More specifically, in 2008, in the study of Tondeur, Valcke, and van Braak, the insufficient material and technical infrastructure and advisory support, and the inadequate supportive school policy, together with the limitative teacher beliefs and negative attitudes with reference to the significance of the introduction of new technological means into instruction, were negatively correlated with their respective utilization. Also, a more frequent use of computers as information tools in the classroom was noted by male rather than by female teachers.

Under a similar rationale, in the studies of Inan and Lowther (2010), and Tountab Haghighi and Eskandari (2012), regardless of teacher gender and working experience, the adverse effect of the teachers' restrictive views, low readiness and lack of know-how on the pedagogical use of ICT was observed on the educational integration of new technological means. Moreover, the insufficiency of the school interactive media equipment and interdisciplinary staffing, conjointly with the afforded technical and advisory support, were negatively associated.

Withal, Hutchison and Reinking (2011), and Kopcha (2012), indicated as deterrents to the pedagogical integration of ICT the teacher perceptions pertaining to the paucity of teaching time in the classroom, and of personal time for the appropriate preparation of courses. Likewise, they mentioned the negative impact of 
the shortage of accessible and reliable technological equipment, of technical assistance and of teacher professional training, plus the scarcity of the corresponding incentives provided in the school environment, on the educational utilization of ICT.

In addition, in the studies of Eickelmann (2011) and Player-Koro (2012), the low teacher self-efficacy and unfavorable stances germane to the usefulness of new technological means in the teaching process and in the future lives of the students, along with the inadequacy of the respective long term, systematic and decentralized administrative guidelines, were negatively correlated with the educational employment of ICT. Yet, no effect of the formal education of the surveyed on new technologies was noticed on their associated instructional practices.

What is more, Ertmer, Ottenbreit-Leftwich, Sadik, Sendurur, and Sendurur (2012), and Tziafetas, Avgerinos, and Karakiza (2013), noted the unfavorable effect of the inadequate building, material and technical laboratory infrastructure, of the increased number of students per class, of the absence of adapted textbooks and of the lack of collegial support and collaboration, in conjunction with the increased teacher working experience, on the innovative pedagogical integration of new technological means. Besides, the present selfefficacy, attitudes and beliefs of the surveyed were negatively correlated with the insufficient teacher pedagogical and vocational training, but also with the limited interdisciplinary and student-centred utilization of ICT.

Lastly, in 2016, in the study of Palaigeorgiou and Grammatikopoulou, the deficient collegial, supervisory, consulting and parental support, and the inadequate school technical infrastructure, as well as the restricted faculty member teaching and personal time, and cognitive resources, were highlighted as inhibitive parameters to the educational inclusion of new technological means. Accordingly, the incompatibility of the pedagogical application of ICT with the curriculum and with the established scholastic assessment system was noticed, together with the schoolteacher overestimation of student skills, and the lack of the relevant teacher training opportunities.

\subsection{Summary}

In the total of the reviewed research, on the one hand, as deterrents to the use of ICT in school, certain interatomic teacher characteristics, such as gender (Tondeur et al., 2008) and low self-efficacy, but also the limitative schoolteacher beliefs and negative stances and perceptions towards the potential utilization of new technological means in education, were indicated (Inan \& Lowther, 2010; Player-Koro, 2012; Tountab Haghighi \& Eskandari, 2012). Additionally, the inadequacy of the necessary faculty member expertise and training, the educators' low teaching preparedness, increased working experience, and teaching and personal time management difficulties, along with the teacher overvaluation of student skills, were identified (Ertmer et al., 2012; Palaigeorgiou \& Grammatikopoulou, 2016; Tziafetas et al., 2013).

On the other hand, the respective impact of particular environmental features, such as the inadequacy and the low accessibility of the building, material and technical school infrastructure, and the insufficiency or the lack of technical, administrative, advisory, collegial and parental support, and of the relevant motivation provided by the school policy, were observed (Badia et al., 2013; Eickelmann, 2011; Hutchison \& Reinking, 2011; Kopcha, 2012). In like manner, the increased number of students in the classrooms and the directions of the curriculum were added (Palaigeorgiou \& Grammatikopoulou, 2016; Tziafetas et al., 2013).

Howbeit, except for two qualitative (Ertmer et al., 2012; Palaigeorgiou \& Grammatikopoulou, 2016) and two mixed methods research studies (Eickelmann, 2011; Kopcha, 2012), the other ones, being surveys, focused primarily on finding connections between the aforementioned variables on an increased range of participants (Cohen, Manion, \& Morrison, 2008). For this reason, a qualitative investigation of specific challenges of the pedagogical utilization of ICT, on a Greek sample of schoolteachers, could provide further explications, elucidation and comprehensive interpretation to the current matter (Berg, 2001; Yin, 2011).

\section{METHODOLOGY}

\subsection{Purpose Of The Study And Research Questions}

The purpose of this study is to examine three interrelated factors that prevent primary school teachers from making use of computers and of other new technological means in their workplace. It is a qualitative, sociological research aiming at an in-depth and holistic description, analysis and understanding of a number of determinants highlighted from previous studies (Mason, 2011). Thus, in view of the research questions approaching the impressions of the participating schoolteachers about particular dissuasive parameters of the pedagogical inclusion of ICT, their singular perceptions, beliefs and motives were scrutinized; in fact, 
their subjective experiences and representations were integrated into the broader value and ideological framework of education's social reality (Cohen et al., 2008; Creswell, 2011; Kiriazi, 2011).

The research questions that were investigated are summarized as follows:

a) What are the main problems encountered by schoolteachers in the use of computers in their workplace?

b) What are the schoolteacher beliefs as to the pedagogical value of the utilization of computers in the teaching process?

c) What is the teachers' school unit of service "official policy" concerning the usage of computers in instructional practice?

\subsection{Data Collection Method}

As method of data collection, personal structured interviews were conducted, allowing the face to face, more immediate documenting, and the more substantive identification of the schoolteacher perceptions with respect to the examined deterring factors. As a hermeneutic instrument of explicit sensitive parameters, expressed verbally and nonverbally, in a climate of trust, and accomplishing interviewee participation, the employed discussion plan could neutralize to a considerable degree potential stereotyped and predefined responses. Moreover, by selecting a predetermined number, sequence and content of questions, formulated by applying a standardized protocol, the exported data codification and comparability was facilitated, whilst increasing the validity and the reliability of the corresponding measurements (Babbie, 2011; Papanastasiou \& Papanastasiou, 2014; Robson, 2010).

\subsection{Data Collection Process And Method Of Analysis}

In April 2016, following our joint decision, the interviews were carried out at participants' homes, outside their teaching hours, in space and time that accommodated their attentional focus in an atmosphere of comfort, security and sincerity. Also, an effort was made to minimize partiality in the interviewers' behavior during the submission of the questions, limiting possible bias and preconceptions of theirs, or interviewees' misapprehension (Cohen et al., 2008; Robson, 2010).

In this context, initially, the respondents were informed clearly about the purpose and the utility of our research and were reassured as concerns the anonymity and the confidentiality of their replies. After their consent, the interviews were recorded. Each interview lasted approximately 25 minutes and included three axes of grouped open-ended questions, redacted in keeping with the current literature: a) teacher's profile, b) history of training and of contact with computers, and c) use or non-use of computers in the workplace. Following their administration, the documented interviews were transcribed and content analysis was performed to the resulting texts with codification of first and second order and classification into conceptual categories. Thusly, based on the method of grounded theory and through continuous comparative method (Verma \& Mallick, 2004), the obtained data were interpreted and conclusions were drawn, in consonance with the forenamed research questions, abiding by a common strategy so as to enhance research validity and reliability (Böhm, 2004; Cohen et al., 2008; Creswell, 2011).

\subsection{Sample Of The Study}

The sample (A) of this study (non-randomized, non-representative sample) consisted of seven primary school teachers in active employment, 5 women and 2 men, of age range 27-56 years (mean age 34.4 years), and of working experience ranging between 2-25 years (mean working experience 7.8 years), employed in public primary schools of equal number in the prefecture of Magnesia, Greece (city of Volos). These specific participants were selected through occasional / convenient sampling, after our communication with the nearest in case available teachers, according to the criteria a) of their abovementioned active working life, as it was feasible for them to provide the data requested for investigation, and $b$ ) of their said educational level of employment (Cohen et al., 2008; Ritchie, Lewis, \& Elam, 2003; Tsiolis, 2014).

\subsection{Research Limitations}

The present study was confined to the prefecture of Magnesia, serving our shared objectives of immediacy of access to the aforesaid sample, of establishment of a relationship of trust with the interviewees, as well as of management of the time limits of the overall research procedure. Hence, the small number of our participants, their unequal distribution of gender and their geographical derivation hindered the generalizability of the research results, reducing their validity and reliability (Maxwell, 2013; Steinke, 2004). 


\section{FINDINGS}

\subsection{Problems Related To Computer Use In The Teachers' Workplace}

Regarding the main problems encountered by schoolteachers in the educational use of computers in their workplace, the inadequate or the insufficient school equipment was reported; characteristically, Participant 2 (P2) mentioned: "(...) in the class that I teach, there is neither a projector, nor an internet connection. Generally, not even half of the classrooms are equipped.". In fact, these challenges were stated in connection with the current directorial, financial and collegial support, as P3 and P4 respectively asserted: "It depends on the administration. (...) we need to consult each other about who will use the computer room.", "There are many needs, but unfortunately economic difficulties render school equipment practically inexistent! (emphatic tone of voice)", in contemplation of student requirements: "...(hesitation) Computers are not contemporary and cannot meet students' needs, since there are many children in the classrooms, and there is no particular intention of the Ministry of obtaining the corresponding infrastructure." (P5).

Also, the inadequate or the insufficient technical assistance in the schools of the interviewees was pointed out: "Technical support exists, but it does not always resolve the problems." (P5), "We have no direct support; therefore, lessons are often interrupted..." (P3), in comparison to collegial cooperation: "(...) the School Principal has no relevant knowledge." (P1), "All colleagues try on our own to help each other... (embarrassment) We have no teacher of informatics at school, so what we do remains between us." (P2).

Moreover, student performance obstacles and pedagogical management of the student population predicaments were attributed to the use of computers in teaching and in children's broader daily lives, as P1 and P3 respectively declared: "Using the dictionary in typing, children are automatically corrected, and are not that much interested about what the books have to say, and this is reasonable.", "Sometimes, there's a difficulty in synchronizing all the students, and especially those of smaller grades, in order to conduct the lesson.".

Furthermore, the inadequacy or the lack of time for the utilization of computers in the respondents' workplace was indicated: "...it's challenging to handle the little time available, during teaching." (P5), "There is not enough time.” (P6).

In addition, the schoolteachers' feeling of pressure was observed with reference to the completion of the syllabus, given the divergence between innovative practice, the curriculum, and the allocated timeframe: "...(pause, thoughtful) (...) it's not so easy to keep up with the curriculum, but also with some original concepts, such as computers, throughout certain teaching hours, apart from the textbooks." (P7).

Finally, the inconvenience of the alternative application of computers in all subjects of the curriculum was expressed: "It's troublesome to make use of computers in all the courses, if you want to do something else, besides worksheets." (P5).

\subsection{Schoolteacher Beliefs Referring To The Pedagogical Value Of The Utilization Of Computers In The Teaching Process}

With respect to the pedagogical significance of the usage of computers in instruction, discourse was delivered about the positive learning outcomes of such a use: "(...) Children work together and are mobilized, they search, they are curious, and eventually they learn! (enthusiasm) (...) lessons become more appealing." (P3), "(...) when the child is provided with audio-visual material, other kinds of stimuli exist and it enters the process of thinking, of drawing conclusions in its own view, and throughout this procedure it's imprinted with information received far more easily." (P6), in virtue of student engagement, collaboration, critical thinking, accountability and autonomy: "(..) attention is directed to children, that are more responsible for performing their assigned activities, they question, they're interested, they judge" (S5), "(...) students decide for their part, they act more independently, without the constant teacher's assistance... (pause)" (P7).

Withal, the coherence of the employment of computers with student-centred and exploratory teaching was respectively perceived by P5 and P7: "Surely computers match with learner-centred instruction, because the role is given to children themselves to learn some things on their own, to seek information, to exercise, to come into contact with other incentives, aside from those that the teacher attempts to provide", "(...) computers most closely match up to student-centred instruction, as well as to the explorative instructive model (...)".

Equally, P3 suggested the integration of computer utilization into grouped cooperative instruction: "Computers are best paired with contemporary teaching methods. Personally, I combine their use with collaborative instruction in groups, in some subjects, of course... (pause)". 
On the contrary, certain views were expressed on the demarcated application of computers in the teaching practice, taking into consideration the educators' teaching style: “...(pause, pensive) Computers are deemed progressive and attract children, but their mode of utilization lies in each schoolteacher himself; it doesn't mean that because you're using a contemporary teaching instrument, you are a modern teacher." (P1), together with the students' learning profiles: "Computers should be used in moderation, at the end of the lessons, and after children have been taught adopting conventional pedagogical methods. (...) live communication must be emphasized." (P2).

\subsection{Teachers' School Unit Of Service "Official Policy" Concerning The Usage Of Computers In Instructional Practice}

As to the "official policy" of the interviewees' schools regarding the educational use of computers, the vague liberty, or the typical endorsement of their present employment were highlighted, ad libitum and depending on the supplied technological equipment: "It's free; anyone who wants to use computers can do so, as much as he believes that it's needed. There isn't something more specific." (P2), "As a faculty, we are all positive towards computer use, but, unfortunately, the country's finances, but also the school's, do not allow the purchase of computers" (P4).

Correspondingly, P5 and P7 remarked the absence of an "official policy", and the "unofficial" abetment or the recompense of the forenamed application of computers: “...(pause, hesitation) (...) if some innovative project takes place, where multimedia and computers are employed, during recess, it's announced to us by the principal in the teachers' office as an example, and it's encouraged through discussion.", "We are not compelled to use computers; however, attempts to use them are rewarded, but, in general, yes, there isn't an 'official policy'.".

Lastly, the absence of an "official policy" apropos of the pedagogical utilization of computers was stressed, in accordance with the teachers' intentions: "On the part of the school, there isn't an 'official policy' requiring the use of computers... (pause) The latter is defined by each teacher's discretion." (P6), or with the available budgetary resources: "I don't think that a school can have an 'official policy', if it doesn't have the necessary funds." (P1).

\section{DISCUSSION AND CONCLUSIONS}

In the present qualitative study, three interlocking deterrents to the utilization of computers and of other new technological means by primary school teachers in their workplace were investigated through individual structured interviews. The exported research results are possible to contribute to a clearer understanding of the said parameters, highlighted by foregoing empirical studies (Badia et al., 2013; Eickelmann, 20111; Ertmer et al., 2012; Hutchison \& Reinking, 2011; Inan \& Lowther, 2010; Kopcha, 2012; Palaigeorgiou \& Grammatikopoulou, 2016; Player-Koro, 2012; Tondeur et al., 2008; Tountab Haghighi \& Eskandari, 2012; Tziafetas et al., 2013).

Firstly, on the subject of the major problems encountered in the use of computers in the teachers' workplace, all 7 participants pointed out the inadequate or the insufficient equipment of their school unit; actually, 5 of them, at times tentatively or categorically, reported the inadequacy of the computers in the classrooms, in order to counterbalance student needs. Likewise, all interviewees noted, occasionally perplexed or troubled, the quantitatively and qualitatively inadequate or insufficient school technical support, considering the various administrative, collegial and economic conditions. Also, 2 female respondents referred to student population low attainment and management difficulties during the educational integration of computers, whereas 2 teachers mentioned the incapacity or the deficiency of teaching time, and their stress in pursuance of the completion of the syllabus. Finally, 1 interviewee indicated the adversity of the original employment of computers in all the disciplines of the curriculum.

By majority, the above findings are consistent with those of Liu and Pange (2015), and of Nikolopoulou and Gialamas (2015), who observed the negative impact of the meager material and technical infrastructure and technical assistance, plus the non-manageable student responsiveness, in conjunction with the inadequate adoption of the pertinent pedagogical models, on the schoolteacher practices germane to the educational implementation of ICT. Besides, the increase and the equitable distribution of the provided school budget and the melioration of the collegial collaboration, along with the undergraduate and the in-service teacher training, were identified by Goktas, Gedik, and Baydas (2013) as significant prerequisites to the pedagogical inclusion of new technological means.

Secondly, as to the schoolteacher beliefs about the pedagogical value of the educational integration of 
computers, 5 out of 7 participants spoke of the auspicious learning outcomes of the present use of new technological means, particularly indicating student mobilization, self-motivation and autonomy. Furthermore, the possibility of combining ICT with student-centered and exploratory teaching, but also with cooperative instruction in groups, was respectively highlighted by 4 and by 1 respondent. Nonetheless, 2 female interviewees expressed opinions in favor of the restrained application of computers in the teaching process, 1 of whom, with 25 years of professional experience, preferring the complementary or the auxiliary role of new technologies to the traditional pedagogical methods, and 1 concerned about the corresponding teacher's role in instructional practice.

By majority, these results are in line with the findings of Blackwell, Lauricella, and Wartella (2014), and of Hermans, Tondeur, van Braak, and Valcke (2008), that noted the positive association of the teacher notions advocating the espousal of learner-centered teaching methods, with the practices of the pedagogical utilization of ICT, as well as the extended teacher work experience with the restrictive schoolteacher beliefs towards the educational inclusion of new technological means. Notably, Zaranis and Oikonomidis (2014) ascertained the positive correlation of the supportive teacher attitudes with reference to the learning outcomes of the educational use of new technologies as cognitive tools, with the increased recent preservice teacher training.

Thirdly, regarding the teachers' school unit of service "official policy" anent the educational integration of computers, certain non-specified formal guidelines of a countenanced facultative usage of ICT, in conjunction with the existing material and technical infrastructure, were highlighted by 3 out of 7 participants. Additionally, 2 respondents, 1 of them hesitantly, spoke of the atypical encouragement of the pedagogical utilization of new technological means, whilst female interviewees of equal number noted the absence of a respective "official policy", contingent upon the teachers' intents, or the per-case economic conditions.

These findings agree with the ones of Ottestad (2013), and of Tondeur, Valcke, and van Braak (2008), who remarked the adverse effect of the inadequate orderly promotive school policy, in particular of the inefficient school principal guidelines pertaining to the instructional incorporation of ICT, on the corresponding schoolteacher stances and effectuated practices. Equally, the negative impact of the dissention between the educational and the administrative policy concerning the employment of new technological means into teaching, on the pedagogical models adopted by every school, was observed by Vanderlinde, Dexter, and van Braak (2012).

Overall, the aforestated results can be applied to the undergraduate and the ongoing in-service professional teacher training, taking into account the afforded national financial resources; more specifically, teachers need to be provided, except for the adequate infrastructure, technical and administrative support, with the updated expertise on the integration of the current available equipment into teaching, and with the related methodological knowledge of student population management (Tsitouridou \& Vryzas, 2004). Moreover, the respective educational authorities ought to seek sufficient awareness of the teachers' beliefs and expectations, within the case-by-case school culture, for the pedagogical utilization of ICT, advancing the latter actively, explicitly and consistently (Frikkie \& Ogunniyi, 2016; Kurt \& Ciftci, 2012).

Nevertheless, for the generalization of the above results, future focalizing on a more representative sample of participants is advised, at first through purposive and then through theoretical sampling, rendering plausible the exportation of an explanatory theoretical model of this issue and its experiences, applicable and in similar contexts (Ritchie et al., 2003). Also, the conduction of a pilot interview and of triangulation of researchers, or sources (e.g. by interviewing School Principals, or School Advisors), together with temporal (i.e. in the course of the evolutionary process of the attendance in primary school) or methodological triangulation (for instance, by systematic or unstructured observation in the classroom), is recommended, for the eventual enhancement of the employed data collection instrument, and for the intersection of the gathered data, respectively (Cohen et al., 2008; Creswell, 2011; Golafshani, 2003).

To conclude, given their empirical accentuation as incentives for the educational use of new technological means (Gialamas \& Nikolopoulou, 2010; Kreijns, van Acker, Vermeulen, \& van Buuren, 2013), the qualitative investigation of the teachers' collegial and parental support, self-efficacy and training, conjointly with the comprehensive evaluation of the content of the associated schoolteachers' undergraduate and in-service training, are proposed, possibly in comparison to data obtained from preschool teachers. In addition, the corresponding examination of pre-service teachers' perceptions, beliefs and attitudes, is suggested. 


\section{REFERENCE LIST}

Afshari, M., Bakar, K. A., Luan, W. S., Samah, B. A., \& Fooi, F. S. (2009). Factors affecting teachers' use of Information and Communication Technology. International Journal of Instruction, 2(1), 77-104. http://files.eric.ed.gov/fulltext/ED524156.pdf

Babbie, E. (2011). Introduction to Social Research (K. Zafiropoulos, Ed., G. Vogiatzis, Trans.). Athens, Greece: Kritiki Publications. (Original work published 1999) [In Greek]

Badia, A., Meneses, J., \& Sigalés, C. (2013). Teachers' perceptions of factors affecting the educational use of ICT in technology-rich classrooms. Electronic Journal of Research in Educational Psychology, 11(3), 787-808. http://dx.doi.org/10.14204/ejrep.31.13053

Berg, B. L. (2001). Qualitative Research Methods for the Social Sciences (4th ed.). Needam Heights, MA: Allyn \& Bacon. https://mthoyibi.files.wordpress.com/2011/05/qualitative-research-methods-for-thesocial-sciences_bruce-l-berg-2001.pdf

Blackwell, C. K., Lauricella, A. R., \& Wartella, E. (2014). Factors influencing digital technology use in early childhood education. Computers \& Education, 77(1), 82-90. http://dx.doi.org/10.1016/j.compedu.2014.04.013

Böhm, A. (2004). Theoretical coding: Text analysis in grounded theory. In U. Flick, E. Von Kardoff, \& I. Steinke (Eds.), A Companion to Qualitative Research (B. Jenner, Trans., pp. 270-275). London, England: Sage.

http://www.jums.ac.ir/Dorsapax/userfiles/file/ACompaniontoqualitativeresearchBOOK.pdf\#page =380 (Original work published 2000)

Buabeng-Andoh, C. (2012). Factors influencing teachers' adoption and integration of information and communication technology into teaching: A review of the literature. International Journal of Education and Development using Information and Communication Technology, 8(1), 136-155.

http://ijedict.dec. uwi.edu//viewarticle.php?id=1361

Cohen, L., Manion, L, \& Morrison, K. (2008). Research Methods in Education (S. Kiranakis, M. Mavraki, C. Mitsopoulou, P. Bithara, \& M. Filopoulou, Trans.). Athens, Greece: Metechmio. (Original work published 2000) [In Greek]

Creswell, J. W. (2011). Educational Research: Planning, Conducting, and Evaluating Quantitative and Qualitative Research (C. Tsorbatzoudis, Ed., N. Kouvarakou, Trans.). Athens, Greece: Ion / Hellene. (Original work published 2002) [In Greek]

Eickelmann, B. (2011). Supportive and hindering factors to a sustainable implementation of ICT in schools. Journal for Educational Research Online, 3(1), 75-103.

http://www.pedocs.de/volltexte/2011/4683/pdf/JERO_2011_1_Eickelmann_Supportive_and_hindering factors_S75_D_A.pdf

Ertmer, P. A., Ottenbreit-Leftwich, A. T., Sadik, O., Sendurur, E., \& Sendurur, P. (2012). Teacher beliefs and technology integration practices: A critical relationship. Computers \& Education, 59(2), 423-435. http://dx.doi.org/10.1016/j.compedu.2012.02.001

Frikkie, G., \& Ogunniyi, M. (2016). Teachers' perceptions on the use of ICT in a CAL environment to enhance the conception of science concepts. Universal Journal of Educational Research, 4(1), 151156. http://dx.doi.org/10.13189/ujer.2016.040119

Gialamas, V., \& Nikolopoulou, K. (2010). In-service and pre-service early childhood teachers' views and intentions about ICT use in early childhood settings: A comparative study. Computers \& Education, 55(1), 333-341. http://dx.doi.org/10.1016/j.compedu.2010.01.019

Goktas, Y., Gedik, N., \& Baydas, O. (2013). Enablers and barriers to the use of ICT in primary schools in Turkey: A comparative study of 2005-2011. Computers \& Education, 68, 211-222. http://dx.doi.org/10.1016/j.compedu.2013.05.002

Golafshani, N. (2003). Understanding reliability and validity in qualitative research. The Qualitative Report, 8(4), 597-606. http://nsuworks.nova.edu/cgi/viewcontent.cgi ?article=1870\&context=tqr

Hermans, R., Tondeur, J., van Braak, J., \& Valcke, M. (2008). The impact of primary school teachers' educational beliefs on the classroom use of computers. Computers \& Education, 51(4), 1499-1509. http://dx.doi.org/10.1016/j.compedu.2008.02.001 
Hutchison, A., \& Reinking, D. (2011). Teachers' perceptions of integrating information and communication technologies into literacy instruction: A national survey in the United States. Reading Research Quarterly, 46(4), 312-333. http://dx.doi.org/10.1002/RRQ.002

Inan, F. A., \& Lowther, D. L. (2010). Factors affecting technology integration in K-12 classrooms: A path model. Educational Technology Research and Development, 58(2), 137-154. http://dx.doi.org/10.1007/s11423-009-9132-y

Kiriazi, N. (2011). Sociological Research: Critical Review of the Methods and of the Techniques. Athens, Greece: Pedio. [In Greek]

Kopcha, T. J. (2012). Teachers' perceptions of the barriers to technology integration and practices with technology under situated professional development. Computers \& Education, 59(4), 1109-1121. http://dx.doi.org/10.1016/j.compedu.2012.05.014

Kreijns, K., van Acker, F., Vermeulen, M., \& van Buuren, H. (2013). What stimulates teachers to integrate ICT in their pedagogical practices? The use of digital learning materials in education. Computers in Human Behavior, 29(1), 217-225. http://dx.doi.org/10.1016/j.chb.2012.08.008

Kurt, S., \& Ciftci, M. (2012). Barriers to teachers' use of technology. International Journal of Instructional Media, 39(3), 225-239.

Liu, X., \& Pange, J. (2015). Early childhood teachers' perceived barriers to ICT integration in teaching: a survey study in Mainland China. Journal of Computers in Education, 2(1), 61-75. http://dx.doi.org/10.1007/s40692-014-0025-7

Livingstone, S. (2012). Critical reflections on the benefits of ICT in education. Oxford Review of Education, 38(1), 9-24. http://dx.doi.org/10.1080/03054985.2011.577938

Mason, J. (2011). Qualitative Researching (N. Kiriazi, Ed., E. Dimitriadou, Trans.). Athens, Greece: Pedio. (Original work published 2002) [In Greek]

Maxwell, J. A. (2013). Qualitative Research Design: An Interactive Approach (3rd ed.). London, England: Sage.

Muir-Herzig, R. G. (2004). Technology and its impact in the classroom. Computers \& Education, 42(2), 111131. http://dx.doi.org/10.1016/S0360-1315(03)00067-8

Nikolopoulou, K., \& Gialamas, V. (2015). Barriers to the integration of computers in early childhood settings: Teachers' perceptions. Education and Information Technologies, 20(2), 285-301. http://dx.doi.org/10.1007/s10639-013-9281-9

Ottestad, G. (2013). School leadership for ICT and teachers' use of digital tools. Nordic Journal of Digital Literacy, 8(1-2), 107-125.

https://www.idunn.no/file/pdf/61221184/school_leadership_for_ict_and_teachers_use_of_digital_tools. pdf

Palaigeorgiou, G., \& Grammatikopoulou, A. (2016). Benefits, barriers and prerequisites for web 2.0 learning activities in the classroom: The view of Greek pioneer teachers. Interactive Technology and Smart Education, 13(1), 2-18. http://dx.doi.org/10.1108/lTSE-09-2015-0028

Papanastasiou, E., \& Papanastasiou, K. (2014). Methodology of Educational Research (2nd ed.). Nicosia, Cyprus: Author. [In Greek]

Player-Koro, C. (2012). Factors influencing teachers' use of ICT in education. Education Inquiry, 3(1), 93108. http://dx.doi.org/10.3402/edui.v3i1.22015

Ritchie, J., Lewis, J., \& Elam, G. (2003). Designing and selecting samples. In J. Richie \& J. Lewis (Eds.), Qualitative Research Practice: A Guide for Social Science Students and Researchers (pp. 77-108). London, England: Sage. http://www.sxf.uevora.pt/wp-content/uploads/2013/03/Ritchie_2003.pdf

Robson, C. (2010). Real World Research (K. Michalopoulou, Ed., V. P. Dalakou \& K. Vasilikou, Trans.). Athens, Greece: Gutenberg. (Original work published 1993) [In Greek]

Smeets, E. (2005). Does ICT contribute to powerful learning environments in primary education? Computers \& Education, 44(3), 343-355. http://dx.doi.org/10.1016/j.compedu.2004.04.003

Steinke, I. (2004). Quality criteria in qualitative research. In U. Flick, E. Von Kardoff, \& I. Steinke (Eds.), A 
Companion to Qualitative Research (B. Jenner, Trans., pp. 184-190). London, England: Sage. http://www.jums.ac.ir/Dorsapax/userfiles/file/ACompaniontoqualitativeresearchBOOK.pdf\#page $=380$ (Original work published 2000)

Tondeur, J., Valcke, M., \& van Braak, J. (2008). A multidimensional approach to determinants of computer use in primary education: Teacher and school characteristics. Journal of Computer Assisted Learning, 24(6), 494-506. http://dx.doi.org/10.1111/j.1365-2729.2008.00285.x

Tondeur, J., van Keer, H., van Braak, J., \& Valcke, M. (2008). ICT integration in the classroom: Challenging the potential of a school policy. Computers \& Education, 51(1), 212-223. http://dx.doi.org/10.1016/j.compedu.2007.05.003

Tountab Haghighi, S., \& Eskandari, M. (2012). A study on barriers of using information technology on learning and teaching in elementary schools. Management Science Letters, 2(1), 417-424. http://dx.doi.org/10.5267/j.msl.2011.07.001

Tsiolis, G. (2014). Methods and Techniques of Analysis in Qualitative Social Research. Athens, Greece: Kritiki Publications. [In Greek]

Tsitouridou, M., \& Vryzas, K. (2004). The prospect of integrating ICT into the education of young children: The views of Greek early childhood teachers. European Journal of Teacher Education, 27(1), 29-45. http://dx.doi.org/10.1080/0261976042000211838

Tziafetas, K., Avgerinos, A., \& Karakiza, T. (2013). Views of ICT teachers about the introduction of ICT in primary education in Greece. TOJET: The Turkish Online Journal of Educational Technology, 12(1), 200-209. http://www.tojet.net/articles/v12i1/12120.pdf

Vanderlinde, R., Dexter, S., \& van Braak, J. (2012). School-based ICT policy plans in primary education: Elements, typologies and underlying processes. British Journal of Educational Technology, 43(3), 505519. http://dx.doi.org/10.1111/j.1467-8535.2011.01191.x

Verma, G. K., \& Mallick, K. (2004). Researching Education: Perspectives and Techniques (A. I. Papastamatis, Ed., E. A. Griva, Trans.). Athens, Greece: Tipothito. (Original work published 1999) [In Greek]

Vitanova, V., Atanasova-Pachemska, T., Iliev, D., \& Pachemska, S. (2015). Factors affecting the development of ICT competencies of teachers in primary schools. Procedia - Social and Behavioral Sciences, 191, 1087-1094. http://dx.doi.org/10.1016/j.sbspro.2015.04.344

Vosniadou, S., \& Kollias, V. (2001). Information and communication technology and the problem of teacher training: Myths, dreams and the harsh reality. Themes in Education, 2(4), 341-365. https://www.researchgate.net/publication/228706932_Information_and_communication_technology_a nd_the_problem_of_teacher_training_Myths_dreams_and_the_harsh_reality

Yin, R. K. (2011). Qualitative Research from Start to Finish. New York, NY: The Guildford Press. https://teddykw2.files.wordpress.com/2012/05/qualitative-research-from-start-to-finish.pdf

Zaranis, N., \& Oikonomidis, V. (2014). The main factors of the attitudes of Greek kindergarten teachers towards information and communication technology. European Early Childhood Education Research Journal. Advance online publication. http://dx.doi.org/10.1080/1350293X.2014.970853 